\title{
Pengaruh Profitabilitas dan Ukuran Perusahaan Terhadap Nilai Perusahaan dengan Strukur Modal sebagai variabel Intervening (Studi pada Perusahaan Manufaktur yang terdaftar di Bursa Efek Indonesia tahun 2017-2019)
}

\author{
Dhian Andanarini Minar Savitri' ${ }^{1)}$, Dian Kurniasari' ${ }^{2)}$, Amos Mbiliyora ${ }^{3)}$ \\ 1,2,3 Program Studi S1 Akuntansi, Sekolah Tinggi Ilmu Ekonomi Totalwin \\ *Email korespondensi: dhian@stietotalwin.ac.id
}

\begin{abstract}
This study aims to analyze the factors that influence firm value with capital structure as a intervening variable in manufacturing companies listed on the Indonesia Stock Exchange in 2017-2019.This research is a causal research with ex post facto type. The population in this study were all manufacturing companies listed on the Indonesia Stock Exchange in 2017-2019. The sampling technique is purposive sampling, which is collecting samples with certain criteria as a benchmark for collection, so that a sample of 141 companies is obtained. Data collection techniques with the method of documentation that is analyzing the company's annual report. Data analysis techniques used to answer the research hypothesis are multiple regression which are operated through the SPSS program.The research shows that profitability and firm size has no effect on firm value, Profitability has a negative effect on capital structure, firm size has a positive effect on capital structure,capital structure has a negative effect on firm value, and capital structure has no proven to mediate the effect of profitability and firm size to firm value.
\end{abstract}

Abstract

Keywords: Financial Performance, Capital Structure, Asset Growth, Company Size, Firm Value.

Saran sitasi: Andriyani, M., \& Mahpudin, E. (2021). Pengaruh Profitabilitas dan Ukuran Perusahaan Terhadap Nilai Perusahaan dengan Strukur Modal sebagai variabel Intervening (Studi pada Perusahaan Manufaktur yang terdaftar di Bursa Efek Indonesia tahun 2017-2019). Jurnal Akuntansi dan Pajak, 21 (2), 500-507. doi:http://dx.doi.org/10.29040/jap.v21i2.1825

DOI: $\underline{\text { http://dx.doi.org/10.29040/jap.v21i2.1825 }}$

\section{PENDAHULUAN}

Salah satu tujuan jangka panjang bagi perusahaan adalah meningkatkan kesejahteraan pemegang saham melalui peningkatan nilai perusahaan. Bagi pemegang saham, keberhasilan suatu perusahaan tercermin pada kenaikan nilai perusahaan. Nilai perusahaan memberikan gambaran kepada para pemegang saham mengenai baik buruknya suatu perusahaan dikelola. Bila manajemen mengelola perusahaan dengan efektif dan efisien maka nilai perusahaan dapat meningkat. Pemegang saham sering melihat kenaikan nilai perusahaan dari harga saham. Harga pasar saham yang meningkat mengindikasikan bahwa nilai perusahaan juga meningkat, (Sudana, 2015). Beberapa faktor yang mempengaruhi nilai perusahaan adalah profitabilitas, ukuran perusahaan dan struktur modal.

Profitabilitas menunjukkan kemampuan perusahaan dalam memperoleh laba dalam periode tertentu. Investor akan tertarik untuk menanamkan saham pada perusahaan yang mempunyai tingkat profitabilitas tinggi, karena dengan profitabilitas tinggi maka return yang diharapkan akan tercapai, (Sudana, 2015). Selain itu profitabilitas menunjukkan kemampuan perusahaan dalam memanfaatkan aset yang dimilikinya untuk digunakan dalam berproduksi dan memperoleh laba yang diharapkan. Dengan demikian profitabilitas dapat diukur dari seberapa besar aset atau modal yang digunakan oleh suatu perusahaan untuk memperoleh laba dalam periode tertentu, (Kusna \& Setijani, 2018). Semakin besar profitabilitas perusahaan diharapkan dapat meningkatkan nilai perusahaan. Semakin besar profitabilitas suatu perusahaan maka ketergantungan perusahaan akan pendanaan eksternal semakin berkurang.

Penelitian Kusna \& Setijani, (2018), Sulastri et al,(2018) serta Mudjijah et al (2019) menyatakan bahwa profitabilitas berpengaruh positif terhadap nilai 
perusahaan. Penelitian Kusna \& Setijani, (2018) menyatakan bahwa profitabilitas berpengaruh negatif terhadap nilai perusahaan. Berbeda dengan penelitian Azmi et al, (2018), menyatakan bahwa profitabilitas tidak berpengaruh terhadap nilai perusahaan.

Penelitian Hermuningsih (2012), Kusna dan Setijani (2018) serta Azmi et al, (2018), menyatakan bahwa profitabilitas berpengaruh negatif terhadap struktur modal.

Faktor lain yang ikut menentukan nilai perusahaan adalah ukuran perusahaan. Semakin besar suatu perusahaan maka semakin banyak pula biaya operasional yang dikeluarkan. Namun demikian di sisi lain semakin besar ukuran suatu perusahaan maka akan semakin mudah untuk mendapatkan sumber pendanaan. Perusahaan juga akan semakin mudah mendapatkan dana melalui pasar modal karena banyak investor yang lebih tertarik untuk menginvestasikan dananya ke perusahaan besar dibandingkan dengan perusahaan kecil.Ukuran perusahaan dapat diukur melalui besarnya asset yang dimiliki oleh suatu perusahaan, (Kusna \& Setijani, 2018).

Penelitian yang dilakukan oleh Sulastri et al (2018) serta Kusna dan Setijani (2018), menyatakan bahwa ukuran perusahaan berpengaruh positif terhadap nilai perusahaan. Berbeda dengan penelitian Slamet et al (2019) yang menyatakan bahwa ukuran perusahaan tidak berpengaruh terhadap nilai perusahaan.

Penelitian yang dilakukan oleh Hermuningsih (2012), menyatakan bahwa ukuran perusahaan berpengaruh positif terhadap struktur modal. Berbeda dengan penelitian Kusna dan Setijani (2018) yang menyatakan bahwa ukuran perusahaan tidak berpengaruh terhadap struktur modal.

Struktur modal dalam suatu perusahaan menjadi pertimbangan yang penting dalam pengambilan keputusan di bidang keuangan, (Azmi et al, 2018). Perusahaan bisa mendapatkan pendanaan dari pihak internal dan dari pihak eksternal. Struktur modal dari internal didapatkan dari penjualan saham serta laba ditahan. Sedangkan struktur modal dari eksternal adalah pemberian kredit dari investor ataupun pihak lain seperti bank. Semakin besar nilai perusahaan akan memberikan kepercayaan kepada investor sehingga perusahaan akan semakin mudah untuk memperoleh modal, baik dengan cara menjual saham maupun dengan mengajukan kredit. Nguyen (2012), menyatakan bahwa struktur modal akan meningkatkan nilai perusahaan, namun bila struktur modal telah mencapai $59,7 \%$, peningkatan selanjutnya dapat menurunkan nilai perusahaan.

Penelitian yang dilakukan oleh Mintarti \& Asmapane, (2018), Cecilia et al., (2015) serta Mudjijah et al., (2019) menyatakan bahwa struktur modal berpengaruh negatif terhadap nilai perusahaan. Berbeda dengan penelitian Sri et al., (2013) menyatakan bahwa struktur modal tidak berpengaruh terhadap nilai perusahaan.

Penelitian ini merupakan replikasi dari penelitian Azmi et al (2018), serta Kusna dan Setijani (2018). Perbedaan penelitian ini dengan penelitian sebelumnya adalah dalam penelitian ini digunakan semua perusahaan manufaktur yang terdaftar di BEI tahun 2017-tahun 2019. Pada penelitian Azmi et al (2018) menggunakan obyek perusahaan farmasi sedangkan penelitian Kusna dan Setijani (2018) menggunakan perusahaan food and beverage sebagai obyek penelitiannya.

\section{Rumusan Masalah}

Rumusan masalah dalam penelitian ini adalah :

a. Apakah profitabilitas berpengaruh positif terhadap nilai perusahaan?

b. Apakah ukuran perusahaan berpengaruh positif terhadap nilai perusahaan?

c. Apakah profitabilitas berpengaruh negatif terhadap ukuran perusahaan?

d. Apakah ukuran perusahaan berpengaruh positif terhadap nilai perusahaan?

e. Apakah struktur modal berpengaruh positif terhadap nilai perusahaan?

f. Apakah struktur modal memediasi pengaruh profitabilitas terhadap nilai perusahaan?

g. Apakah struktur modal memediasi pengaruh ukuran perusahaan terhadap nilai perusahaan?

\section{Tujuan Penelitian}

Tujuan dari penelitian ini adalah untuk mengetahui dan menganalisis pengaruh profitabilitas dan ukuran perusahaan terhadap nilai perusahaan, pengaruh profitabilitas dan ukuran perusahaan terhadap struktur modal, serta pengaruh profitabilitas dan ukuran perusahaan terhadap nilai perusahaan dengan mediasi struktur modal.

\section{Signaling Theory}

Teori sinyal menyatakan bahwa perusahaan dapat memberikan sinyal yang baik kepada investor dan masyarakat mengenai laporan keuangan. Secilia et al (2015) . Menjelaskan bahwa terjadi reaksi pasar yaitu ditandai dengan perubahan harga dan volume perdagangan saham atas sinyal yang diberikan oleh 
perusahaan. Jika sinyal yang diberikan oleh perusahaan tersebut baik atau Good News maka reaksi pasarpun akan baik dan berdampak pada kenaikan pada kinerja keuangan, pertumbuhan aset dan ukuran perusahaan. Nilai perusahaan yang tinggi juga memberikan sinyal bahwa perusahaan akan lebih mendapat .kepercayaan dari investor bila mengajukan pendanaan yang berasal dari hutang.

Kaitan antara teori sinyal terhadap nilai perusahaan yang dimana perusahaan memberikan sinyal positif berupa informasi yang baik kepada investor. Dengan adanya sinyal berupa informasi yang baik diharapkan investor akan tertarik sehingga kinerja keuangan akan meningkat, adanya pertumbuhan aset, ukuran perusahaanpun meningkat dan kreditorpun akan lebih percaya untuk memberikan pendanaan berupa hutang kepada perusahaan.

\section{Pecking Order Theory}

Teori pecking order berkaitan erat dengan struktur modal suatu perusahaan. Perubahan struktur modal terjadi ketika suatu perusahaan membutuhkan pendanaan jangka panjang. Pendanaan ini bisa dari internal maupun eksternal perusahaan. Dalam teori Pecking order dijelaskan urutan pendanaan suatu perusahaan di mana perusahaan pertama akan menggunakan laba ditahan, kemudian hutang dan terakhir adalah menerbitkan saham, (Azmi et al, 2018).

\section{Nilai Perusahaan}

Nilai perusahaan adalah pandangan investor mengenai perusahaan yang biasanya dilhat melalui harga saham. Dalam penelitian ini nilai perusahaan diukur menggunakan Price to Book Value (PBV). Nilai PBV mencerminkan harga saham perusahaan. Semakin besar nilai PBV maka harga saham perusahaan tersebut bisa dikatakan mahal dan menjadi cerminan bahwa nilai perusahaan tinggi, demikian pula sebaliknya, (Mudjijah et al, 2019).

$$
\text { Price to Book Value }=\frac{\text { Harga pasar per lembar saham }}{\text { Nilai buku per lembar saham }}
$$

\section{Struktur Modal}

Struktur modal adalah komposisi pendanaan yang digunakan oleh perusahaan. Dalam penelitian ini struktur modal diukur menggunakan Debt to Equity Ratio (DER). DER merupakan rasio keuangan yang membandingkan antara hutang yang digunakan perusahaan dengan modal sendiri, (Hermuningsih, 2012).

$$
D E R=\frac{\text { Total Hutang }}{\text { Total ekuitas }}
$$

\section{Profitabilitas}

Profitabilitas adalah kemampuan suatu perusahaan untuk memperoleh laba dalam suatu periode tertentu, (Kusna dan Setijani, 2018). Dalam penelitian ini profitabilitas diukur menggunakan Return On Assets (ROA). ROA melihat profitabilitas dari sudut pandang aset yang digunakan oleh perusahaan untuk memperoleh laba, (Rismawati, 2016)

$$
R O A=\frac{\text { Laba Bersih }}{\text { Total aset }}
$$

\section{Ukuran Perusahaan}

Menurut Halim \& Sarwoko (2014), Ukuran perusahaan merupakan besar kecilnya perusahaan, baik dari segi jumlah aktiva maupun dari segi tingkat penjualan, akan sangat mempengaruhi besarnya modal kerja sehingga perusahaan besar cenderung akan diversifikasi dan lebih tahan terhadap resiko kebangkrutan dan memiliki kemungkinan lebih rendah mengalami kesulitan keuangan. Dalam penelitian ini ukuran perusahaan diukur menggunakan logaritma natural dari total aset.

$$
\text { Ukuran perusahaan }=\ln \text { Total aset }
$$

\section{Kerangka Pemikiran}

Kerangka penelitian dalam penelitian ini adalah sebagai berikut :

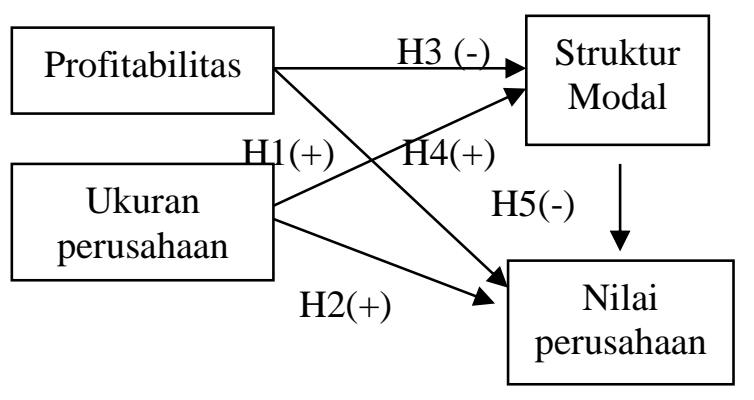

Gambar 1

Kerangka Pemikiran

\section{Hipotesis}

Hipotesis dalam penelitian ini :

$\mathrm{H} 1$ : Profitabilitas berpengaruh positif terhadap nilai perusahaan

$\mathrm{H} 2$ : Ukuran perusahaan berpengaruh positif terhadap nilai perusahaan

H3 : Profitabilitas berpengaruh negatif terhadap struktur modal

H4 : Ukuran perusahaan berpengaruh positif terhadap struktur modal 
H5 : Struktur modal berpengaruh negatif terhadap nilai perusahaan

H6 : Struktur modal mampu memediasi pengaruh profitabilitas terhadap nilai perusahaan

H7 : Struktur modal mampu memediaso pengaruh ukuran perusahaan terhadap nilai perusahaan

\section{METODE PENELITIAN}

\section{Populasi dan Sampel}

Penelitian ini menggunakan populasi seluruh perusahaan manufaktur yang tercatat di Bursa Efek Indonesia dari tahun 2017 sampai tahun 2019 serta menerbitkan laporan keuangan secara lengkap.

Metode yang digunakan untuk menentukan sampel dalam penelitian ini adalah purposive sampling. Berdasarkan metode tersebut maka banyaknya perusahaan manufaktur yang dapat dijadikan sampel adalah sebanyak 141 perusahaan.

\section{Teknik Pengumpulan Data}

Data yang digunakan dalam penelitian ini adalah data sekunder yang diambil dari laporan keuangan perusahaan yang diunduh dari webside IDX.

\section{Teknik Analisis Data}

Data yang digunakan dalam penelitian ini sebanyak 423 data (141 perusahaan x 3 tahun). Dalam proses olah data melalui program SPSS terdapat outlier data sebanyak 218 data, sehingga data yang diolah adalah 205 data.

\section{HASIL DAN PEMBAHASAN}

\subsection{Hasil Penelitian}

\section{Uji Asumsi Klasik}

\section{Uji Normalitas}

Dari gambar 2 nampak bahwa grafik histogram menunjukkan pola distribusi normal di mana grafik memiliki titik kelengkungan yang sama pada sisi kiri maupun sisi kanan.

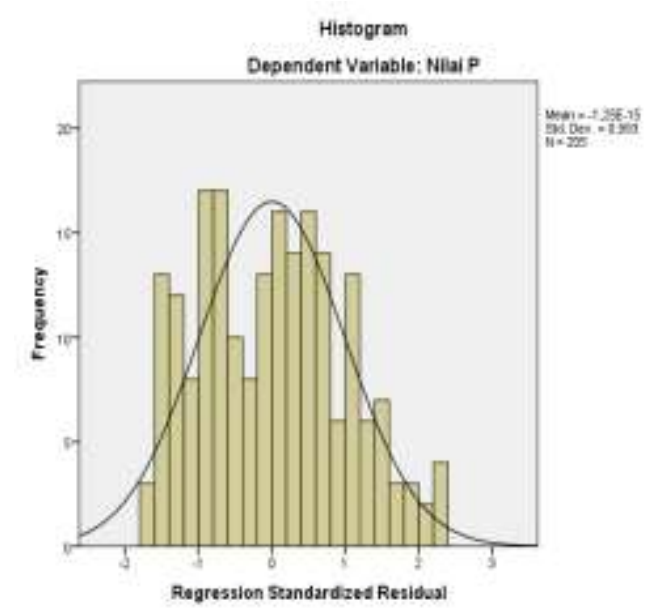

Dari tabel 1 dapat dilihat bahwa besarnya nilai Asymp sig adalah sebesar 0,155 di mana nilai tersebut lebih besar dari 0,05 sehingga dapat dikatakan bahwa data terdistribusi normal.

Tabel 1

Uji Normalitas (Kolmogorof Smirnov)

NPar Tests

One-Sample Kolmogorov-Smirnov Test

\begin{tabular}{|ll|r|}
\hline & & $\begin{array}{r}\text { Unstandardized } \\
\text { Residual }\end{array}$ \\
\hline $\mathrm{N}$ & Mean & 205 \\
Normal & Std. Deviation &, 495950000 \\
Parameters ${ }^{\mathrm{a}, \mathrm{b}}$ & Absolute &, 079 \\
Most Extreme & Positive &, 079 \\
Differences & Negative &,- 044 \\
Kolmogorov-Smirnov Z & 1,130 \\
Asymp. Sig. (2-tailed) &, 155 \\
\hline
\end{tabular}

a. Test distribution is Normal.

b. Calculated from data.

\section{Uji Multikolinearitas}

Variabel bebas dalam suatu penelitian dikatakan bebas dari multikolinearitas ketika nilai VIF < 10 dan nilai tolerance $>0,1$ (Ghozali, 2013). Dari tabel 2 dapat dilihat bahwa nilai VIF untuk semua variabel < 10 dan nilai tolerance untuk semua variabel $>0,1$. Dari hasil tersebut dapat dikatakan bahwa seluruh variabel bebas dalam penelitian ini tidak ada gejala multikolinearitas.

Tabel 2

Uji Multikolinearitas

Coefficients $^{\mathrm{a}}$

\begin{tabular}{|ll|r|r|}
\hline \multirow{2}{*}{ Model } & \multicolumn{2}{|c|}{ Collinearity Statistics } \\
\cline { 2 - 3 } & Tolerance & \multicolumn{1}{c|}{ VIF } \\
\hline \multirow{3}{*}{1 (Constant) } & & \\
& Profit &, 978 & 1,023 \\
& Size &, 962 & 1,039 \\
& S-MOdal &, 961 & 1,041 \\
\hline
\end{tabular}

a. Dependent Variable: Nilai P

\section{Uji Heteroskedastisitas}

Uji Heteroskedastisitas dapat dilakukan dengan melihat diagram scatterplot. Gambar 3 menunjukkan scatterplot data dalam penelitian ini. titik-titik terlihat menyebar dan tidak membentuk suatu pola sehingga dapat dikatakan bahwa data tidak terjadi heteroskedastisitas.

Gambar 2. Histogram 


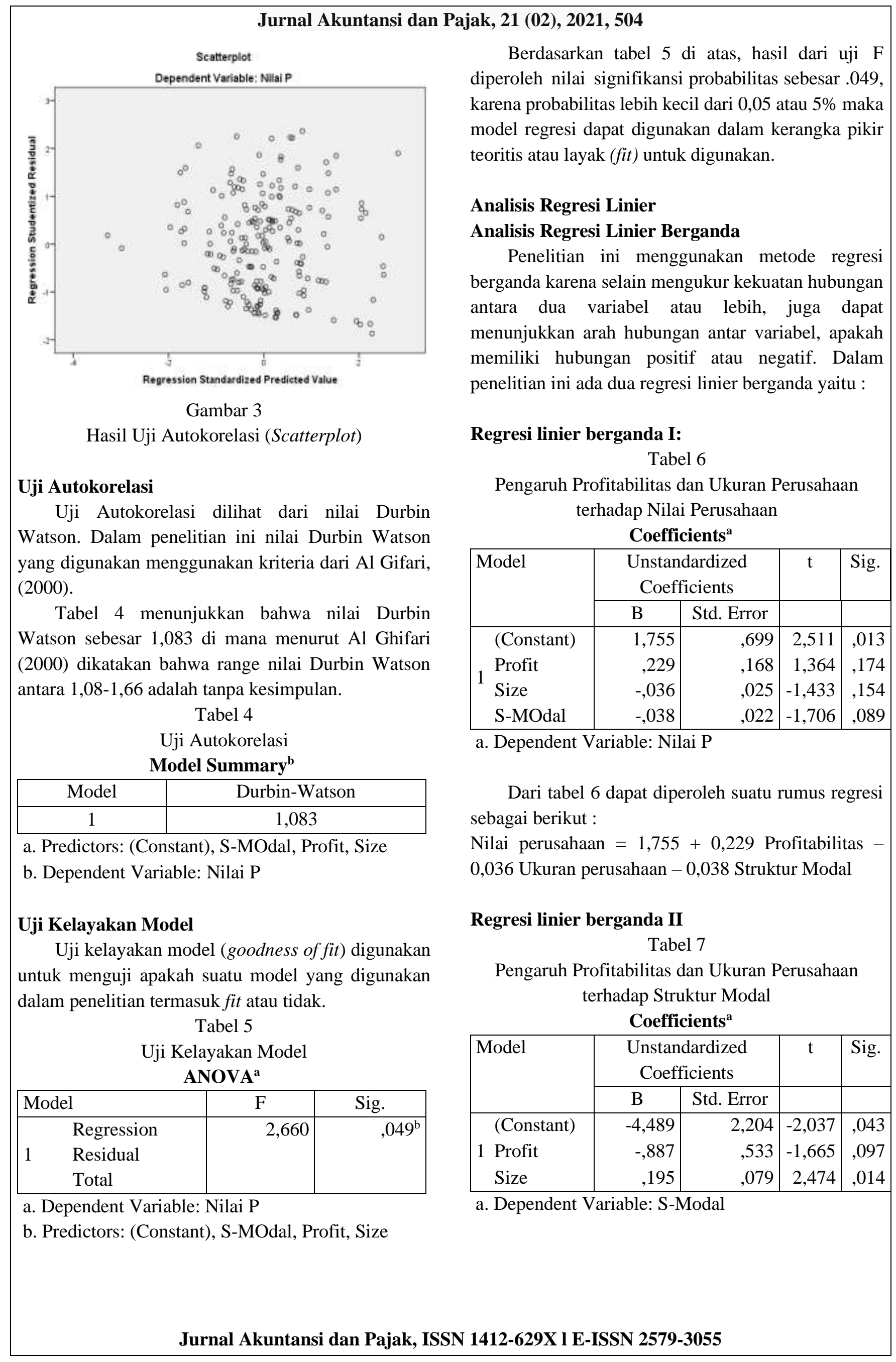


Dari Tabel 7 dapat diperoleh rumus regresi sebagai berikut :

Struktur modal $=-4,489-0,887$ Profitabilitas $+0,195$ Ukuran perusahaan

\section{Analisis Regresi Linier Sederhana}

Regresi Linier sederhana dilakukan untuk melihat pengaruh struktur modal terhadap nilai perusahaan. Hasil olah data dapat dilihat di tabel 8 .

Tabel 8

Pengaruh Struktur Modal terhadap Nilai Perusahaan Coefficients $^{\mathbf{a}}$

\begin{tabular}{|c|c|c|c|c|}
\hline \multirow[t]{2}{*}{ Model } & \multicolumn{2}{|c|}{$\begin{array}{l}\text { Unstandardized } \\
\text { Coefficients }\end{array}$} & \multirow[t]{2}{*}{$\mathrm{t}$} & \multirow[t]{2}{*}{ Sig. } \\
\hline & B & Std. Error & & \\
\hline (Constant) & ,776 & , 040 & 19,406 & ,000 \\
\hline S-MOdal &,- 046 & ,022 & $-2,104$ & ,037 \\
\hline
\end{tabular}

a. Dependent Variable: Nilai P

Dari tabel 8 dapat diperoleh rumus regresi sebagai berikut :

Nilai perusahaan $=0,776-0,046$ Struktur Modal

\section{Uji t}

Dari tabel 6 dapat dijelaskan bahwa nilai signifikansi untuk variabel profitabilitas adalah sebesar 0,174 di mana lebih besar daripada 0,05 . Nilai t sebesar 1,364 sehingga dapat dikatakan bahwa profitabilitas tidak berpengaruh terhadap nilai perusahaan.

Dari tabel 6 dapat dijelaskan bahwa nilai signifikansi untuk variabel ukuran perusahaan adalah sebesar 0, 154 di mana lebih besar daripada 0,05 dan nilai $\mathrm{t}$ sebesar $-1,433$ sehingga dapat disimpulkan bahwa ukuran perusahaan tidak berpengaruh terhadap nilai perusahaan.

Dari tabel 7 dapat dilihat bahwa nilai signifikansi untuk variabel profitabilitas adalah sebesar 0,097 yang lebih kecil dari 0,1 apabila digunakan probabilitas $10 \%$, Nilai t ditunjukkan sebesar $-1,665$ yang artinya adalah bahwa profitabilitas berpengaruh negatif signifikan terhadap struktur modal.

Dari tabel 7 dapat dijelaskan bahwa nilai signifikansi dari variabel ukuran perusahaan adalah sebesar 0,014 yang lebih kecil daripada 0,05 . Nilai $t$ ditunjukkan sebesar 2,474 sehingga dapat dikatakan bahwa ukuran perusahaan berpengaruh positif terhadap struktur modal.

Dari tabel 8 nampak bahwa nilai signifikansi untuk variabel struktur modal adalah sebesar 0,037 di mana lebih kecil daripada 0,05 . Nilai t sebesar $-2,104$ sehingga dapat dikatakan bahwa struktur modal berpengaruh negatif terhadap nilai perusahaan.

\section{Uji Koefisien Determinasi}

Uji koefisien determinasi digunakan untuk mengukur seberapa jauh kemampuan model dalam menerangkan variasi variabel independen terhadap variabel dependen.

\section{Tabel 9}

Uji Koefisien Determinasi Variabel Independen terhadap Nilai Perusahaan

\begin{tabular}{|l|c|r|r|r|}
\multicolumn{5}{c|}{ Model Summary $^{\mathbf{b}}$} \\
\hline Model & $\mathrm{R}$ & $\begin{array}{c}\mathrm{R} \\
\text { Square }\end{array}$ & $\begin{array}{c}\text { Adjusted R } \\
\text { Square }\end{array}$ & $\begin{array}{l}\text { Std. Error of } \\
\text { the Estimate }\end{array}$ \\
\hline 1 &, $195^{\mathrm{a}}$ &, 038 &, 024 &, 49964 \\
\hline
\end{tabular}

a. Predictors: (Constant), S-MOdal, Profit, Size

b. Dependent Variable: Nilai P

Berdasarkan tabel 9 di atas diperoleh nilai koefisien determinasi (Adjusted $R$ Square) sebesar 0,024 hal ini berarti $2,4 \%$ variasi nilai perusahaan dapat dijelaskan oleh variasi dari kedua variabel independen yaitu profitabilitas dan ukuran perusahaan, sedangkan sisanya (100\%-2,4\%) $97,6 \%$ dipengaruhi oleh variabel lain.

Tabel 10

Uji Koefisien Determinasi Variabel Independen terhadap Struktur Modal

Model Summary ${ }^{\mathrm{b}}$

\begin{tabular}{|l|c|r|r|r|}
\hline Model & $\mathrm{R}$ & $\begin{array}{c}\mathrm{R} \\
\text { Square }\end{array}$ & $\begin{array}{c}\text { Adjusted R } \\
\text { Square }\end{array}$ & $\begin{array}{c}\text { Std. Error of } \\
\text { the Estimate }\end{array}$ \\
\hline 1 &, $197^{\mathrm{a}}$ &, 039 &, 029 & 1,59218 \\
\hline
\end{tabular}

a. Predictors: (Constant), Size, Profit

b. Dependent Variable: S-Modal

Berdasarkan tabel 10 di atas diperoleh nilai koefisien determinasi (Adjusted $R$ Square) sebesar 0,029 hal ini berarti $2,9 \%$ variasi struktur modal dapat dijelaskan oleh variasi dari kedua variabel independen yaitu profitabilitas dan ukuran perusahaan, sedangkan sisanya $(100 \%-2,9 \%) \quad 97,1 \%$ dipengaruhi oleh variabel lain.

\section{Sobel Test}

Uji sobel dilakukan untuk menguji kekuatan pengaruh tidak langsung $\mathrm{X}$ terhadap $\mathrm{Y}$ melalui variabel intervening. Hasil Sobel test dapat dilihat di tabel 11. Dari sobel test didapatkan hasil bahwa nilai sobel test untuk kedua variabel independen berada di 
bawah 1,96 dan nilai signifikansi lebih besar dari 0,05 sehingga dapat disimpulkan bahwa struktur modal tidak dapat memediasi pengaruh profitabilitas terhadap nilai perusahaan dan pengaruh ukuran perusahaan terhadap nilai perusahaan.

Tabel 11

Hasil Sobel Test

\begin{tabular}{|l|c|c|}
\hline \multicolumn{1}{|c|}{ Variabel } & Sobel test & Nilai sig \\
\hline Profitabilitas & 1,30209153 & 0,09644255 \\
\hline Ukuran perusahaan & $-1,59543755$ & 0,05530721 \\
\hline
\end{tabular}

\subsection{Pembahasan}

\section{Pengaruh Profitabilitas terhadap Nilai Perusahaan}

Hasil penelitian ini sejalan dengan hasil penelitian Azmi et al, (2019) yang mengungkapkan bahwa profitabilitas tidak berpengaruh terhadap nilai perusahaan. Hal ini menunjukkan bahwa besar ataupun kecilnya laba yang diperoleh oleh perusahaan tidak berpengaruh kepada nilai perusahaan.

Rasio keuangan di atas tidak dapat dijadikan acuan sepenuhnya dalam menilai pengaruh kinerja keuangan terhadap nilai perusahaan. Dalam penelitian ini proksi untuk variabel profitabilitas adalah ROA. Besar kecilnya aset yang digunakan oleh perusahaan untuk menghasilkan laba tidak dapat mempengaruhi nilai perusahaan.

\section{Pengaruh Ukuran Perusahaan terhadap Nilai Perusahaan}

Hasil penelitian ini sejalan dengan penelitian yang dilakukan oleh Slamet et al, (2019) yang menunjukkan bahwa ukuran perusahaan tidak berpengaruh terhadap nilai perusahaan. Hal ini menunjukkan bahwa besar atau kecilnya perusahaan bukan menjadi pertimbangan bagi investor untuk berinvestasi.

Ukuran perusahaan yang besar belum bisa menjamin nilai perusahaannya tinggi, karena perusahaaan yang besar mungkin belum berani melakukan investasi baru terkait dengan ekspansi, sebelum kewajiban-kewajibannya sudah terlunasi.

\section{Pengaruh Profitabilitas terhadap Struktur Modal}

Hasil penelitian ini sejalan dengan penelitian yang dilakukan oleh Hermuningsih (2012), Kusna dan Setijani (2018) serta Azmi et al, (2018), yang menunjukkan bahwa profitabilitas berpengaruh negatif terhadap struktur modal. Hal ini menunjukkan bahwa perusahaan yang memiliki tingkat keuntungan lebih tinggi akan menggunakan utang yang relatif lebih kecil dibandingkan perusahaan dengan keuntungan yang rendah. Tingkat keuntungan yang tinggi memungkinkan mereka untuk memperoleh sebagian besar pendanaan dari laba ditahan. Perusahaan akan cenderung memilih laba ditahan untuk membiayai sebagian besar kebutuhan pendanaan.

\section{Pengaruh Ukuran Perusahaan terhadap Struktur Modal}

Hasil penelitian ini mendukung hasil penelitian Hermuningsih (2012), yang menunjukkan bahwa ukuran perusahaan berpengaruh positif terhadap struktur modal. Sering dikatakan bahwa banyak perusahaan kecil yang masih mengandalkan pinjaman dari pihak lain untuk beroperasi dan mengembangkan perusahaannya, namun demikian tidak menutup kemungkinan bagi perusahaan besar untuk melakukan peminjaman kepada pihak lain untuk berekspansi memperbesar perusahaannya. Bagi perusahaan besar justru akan semakin mudah memperoleh pinjaman dari kreditur karena kreditur merasa percaya akan kinerja perusahaan tersebut.

\section{Pengaruh Struktur Modal terhadap Nilai Perusahaan}

Hasil penelitian ini mendukung hasil penelitian yang dilakukan oleh Mintarti \& Asmapane, (2018), Cecilia et al., (2015) serta Mudjijah et al., (2019), yang menunjukkan bahwa struktur modal berpengaruh negatif terhadap nilai perusahaan. Semakin besar hutang yang dimiliki perusahaan dapat membuat investor menjadi ragu untuk berinvestasi. Tingginya hutang dapat menurunkan performa perusahaan di mata investor sehingga akibatnya harga saham bisa menurun. Harga saham yang turun mencerminkan nilai perusahaan yang menurun.

Pengaruh Profitabilitas terhadap Nilai Perusahaan dengan Struktur Modal sebagai Variabel Intervening

Hasil penelitian menunjukkan bahwa struktur modal tidak mampu memediasi pengaruh profitabilitas terhadap nilai perusahaan.

Pengaruh Ukuran Perusahaan terhadap Nilai Perusahaan dengan Struktur Modal sebagai Variabel Intervening

Hasil penelitian menunjukkan bahwa struktur modal tidak mampu memediasi pengaruh profitabilitas terhadap nilai perusahaan.

\section{KESIMPULAN}

Kesimpulan dari penelitian ini adalah profitabilitas dan ukuran perusahaan tidak 
berpengaruh terhadap nilai perusahaan. Profitabilitas berpengaruh negatif terhadap struktur modal sedangkan ukuran perusahaan berpengaruh positif terhadap struktur modal. Struktur modal berpengaruh negatif terhadap nilai perusahaan. Struktur modal tidak dapat memediasi baik pengaruh profitabilitas maupun pengaruh ukuran perusahaan terhadap nilai perusahaan.

Saran yang dapat diberikan dalam penelitian ini adalah agar perusahaan memperhatikan faktor-faktor yang dapat mempengaruhi peningkatan nilai perusahaan. Jika nilai perusahaan naik maka diharapkan investor akan lebih tertarik untuk menanamkan dananya dan pada akhirnya kesejahteraan para pemegang saham dapat meningkat.

Bagi penelitian mendatang hendaknya menambahkan faktor lain yang dapat mempengaruhi nilai perusahaan serta tidak hanya menggunakan data perusahaan manufaktur tetapi juga menyertakan perusahaan go public di luar perusahaan manufaktur.

\section{REFERENSI}

Algifari. (2000), Analisis Regresi, Teori, Kasus dan Solusi (2nd ed.), Yogyakarta: BPFE.

Azmi, N., Isnurhadi, Hamdan, U., (2018), Pengarih Profitabilitas, Ukuran Perusahaan terhadap Nilai Perusahaan dengan Struktur Modal sebagai Variabel Intervening pada Perusahaan Manufaktur yang terdaftar di BEI, Jurnal Ilmiah Manajemen dan Bisnis Terapan (JEMBATAN), Tahun XV No. 2, Universitas Sriwijaya, Palembang.

Cecilia, Rambe, S., \& Torong, M. Z. B. (2015). Analisis Pengaruh Corporate Social Responsibility , Profitabilitas dan Ukuran Perusahaan Terhadap Nilai Perusahaan. Akuntansi, 1, 1-22.

Halim, A., \& Sarwoko, S. (2014). Manajemen Keuangan (Dasar-Dasar Pembelanjaan Perusahaan) Buku 1: Manajemen dan Analisis Aktiva (2nd ed.). Yogyakarta: BPFE Yogyakarta. Hermuningsih, S. (2012), Pengaruh Profitabilitas , Growth Opportunity, Sruktur Modal Terhadap Nilai Perusahaan Pada Perusahaan Publik di Indonesia, Jurnal Siasat Bisnis, Vol, 16 No. 2, Universitas Islam Indonesia, Yogyakarta.

Ghozali, I. (2013). Aplikasi Analisis Multivariate Dengan Program IBM SPSS 21 (7th ed.). Semarang: Badan Penerbit Universitas Diponegoro.
Kristiyanti, LMS., Abdul Haris R., Alfiana Kristi, (2019), Analisis Pengaruh Marketing Activity Dan Working Capital Terhadap Profitabilitas Di PT Kraakatausteel Tahun 2010 - 2018, Jurnal Akuntansi dan Pajak, Vol 20 No.01, LPPM STIE AAS, http://dx.doi.org/10.29040/jap.v20i1.542

Kusna, I., Setijani, E., (2018), Analisis Pengaruh Kinerja Keuangan, Growth Opportunity dan Ukuran Perusahaan terhadap Struktur Modal dan Nilai Perusahaan, Jurnal Manajemen dan Kewirausahaan, Vol. 6 No. 1, Universitas Merdeka, Malang.

Mintarti, S., \& Asmapane, S. (2018). Pengaruh struktur modal, kinerja keuangan perusahaan, ukuran perusahaan dan kualitas auditor eksternal terhadap nilai perusahaan pada perusahaan manufaktur yang terdaftar di bursa efek indonesia. 15(1), 1-11.

Mudjijah, S., Khalid, Z., \& Astuti, D. A. S. (2019). Pengaruh Kinerja Keuangan Dan Struktur Modal Terhadap Nilai Perusahaan Yang Dimoderasi Variabel Ukuran Perusahaan. Journal of Chemical Information and Modeling, 53(9), 1689-1699.

https://doi.org/10.1017/CBO9781107415324.00 $\underline{4}$

Rismawati, N. M., \& Dana, I. M. (2007). Pengaruh Pertumbuhan Aset, Tingkat Bunga Sertifikat Bank Indonesia (SBI) Terhadap Kebijakan Dividen dan Nilai Perusahaan Pada Perusahaan Manufaktur Di Bursa Efek Indonesia (BEI). 9881004.

Slamet, M., Zulvia, K., \& Sekar, A. D. A. (2019). Pengaruh Kinerja Keuangan Dan Struktur Modal Terhadap Nilai Perusahaan Yang Dimoderasi Variabel Ukuran Perusahaan. 8(1), 41-56.

Sri, A., Dewi, M., \& Wirajaya, A. (2013). Pengaruh Struktur Modal, Profitabilitas Dan. 2, 358-372.

Sudana, I Made, 2015, Manajemen Keuangan Perusahaan Teori dan Praktik, Edisi kedua, Erlangga, Jakarta.

Sulastri et al, (2019), Pengaruh Profitabilitas terhadap Nilai Perusahaan dengan Struktur Modal sebagai Variabel Intervening pada Perusahaan Pembiayaan yang Terdaftar di BEI, Jurnal DISTRIBUSI, Jurnal Ilmu Manajemen dan Bisnis,Vol. 7 No. 2, Universitas Mataram, Mataram. 